\title{
The internationalization of higher educa- tion in Europe: a discussion of English as a medium of instruction and its implica- tions for (in)equalities ${ }^{1}$
}

\author{
Klarissa Lueg (klueg@sdu.dk) \\ University of Southern Denmark, Denmark
}

1. Introduction: the Internationalization of higher education The internationalization of higher education (HE) is developing rapidly, and a large number of publications have emphasized the importance of this process (Ennew/Greenaway 2012; Maringe/Foskett 2013; Maassen/Uppstrøm 2004). With respect to HE, the OECD defines internationalization as sthe integration of an international/intercultural dimension into all the activities of a university, including teaching, research and service functions « (OECD 1999). Whereas Kreber (2009) calls attention to the connotation of internationalization that is linked to economic pressure, others similarly link internationalization to new public management (de Haan 2014; Kristensen et al. 2011; Lueg 2014). Since the Bologna process, in particular, European governments have urged universities to establish internationalization strategies and have indicated that developing such strategies is a "requirement for modern academia (BMBF 2014). Researchers have investigated many aspects of internationalization, including cooperation and mobility, in particular (Aba 2013; Aittola et al. 2009; Berchem 1991; Kim 2009). Another key consequence of internationalization processes in HE is the rise of English as the language of HE (LHE) (Ammon/McConnell 2002) and, more specifically, the rise of English as the medium of instruction (EMI) in HE (de Haan 2014; Lueg/Lueg 2015). EMI is on the rise in most European countries and is strongly advocated by many governments. Research on implementing EMI in internationalization processes ties in with research on education and social stratification and inequality. Critical

\footnotetext{
${ }^{1}$ This article has been published in a similar version in: Graf, A., Möller, C. (Eds.), (2015). Bildung-Macht- Eliten: Zur Reproduktion sozialer Ungleichheiten. Campus Verlag.
} 
management studies have addressed issues related to internationalization, higher education and/or the reproduction of elites and social inequalities (Doh 2010; Engwall 2004; Hartmann 2000; 2010; Lueg/Lueg 2015; Vaara/Faÿ 2011). EMI, which is associated with better job opportunities and prestige, is predominantly preferred by students from higher socioeconomic strata, whereas students from lower socioeconomic strata with similar English proficiency are more inclined to fear barriers to EMI such as risk of dropout and/or exam failure (Lueg/Lueg 2015). Research from Asia has directly related class issues to the costs of tutoring and/or traveling abroad to prepare students for the shift to EMI (Jeong 2004; Kang 2012). Although the linkage between $\mathrm{EMI}$ and social inequality permeates the public debate, there are only a few systematic scholarly studies on the subject. This paper provides an overview of the current debates related to EMI in Europe. Although this paper takes a critical view of the potentially socially stratifying effects of EMI, it also aims to identify avenues to an accessible HE system with EMI. The remainder of this paper is organized as follows. Section 2 reports the status of and perspectives on EMI in Europe. Section 3 reports on the status of EMI and internationalization as well as on current debates on the subject in Germany, in particular. Section 4 discusses five claims that tie EMI to the debate regarding social inequality and elitism. Finally, section 5 discusses and suggests the implications of an adequate integration of EMI into $\mathrm{HE}$.

\section{EMI IN EUROPE}

Despite the common view that English has been established as ॥ [...] the language of higher education « in Europe (Coleman 2004), systematic quantitative investigation of the status of EMI is scarce (as an exception s. Wächter/Maiworm 2008). Today, German HE institutions offer 932 full programs completely in EMI (DAAD 2015a), and the Danish Ministry of Higher Education and Science lists 500 full degree EMI programs over all Danish HE institutions (2015). Maiworm and Wächter (2008: 29) identified a north-south divide with respect to EMI in which France and Italy represent countries with particularly low offerings of EMI programs, and countries such as Cyprus, Sweden, Switzerland, and Hungary occupy the top and middle ranges of EMI offerings. The rise of EMI has sparked a critical debate among scholars, journalists and politicians that mainly focuses on the four perspectives and several arguments outlined below (s. table 1) (for a similar discussion of the Danish discourse s. Lueg 2015). The perspective that advocates for EMI is the internationalized knowledge economy perspective, which consists of both the organizational competition argument and the career argument. Specifically, universities argue that attracting foreign students and preparing domestic students for the global labor market are equally important rationales (84\%) (Wächter/Maiworm 2008). Students advocate for increases in EMI and consider it an avenue to career opportunities in both social and natural science programs (Byun et al. 2011; Costa/Coleman 2012; Knapp 2011). Pushed by the competitive aspects of the Bologna treaties, governments have urged institutions of HE to offer substantial shares of their study programs in English (e.g. GWK 2013). The second perspective on EMI is the language and teaching quality perspective, which comprises the capability argument. Despite their generally positive attitude toward EMI, students sometimes perceive lecturers' language skills as inadequate (Haastrup 2008; Jensen et al. 2013). This view seems to echo the reasons why universities oppose 
the introduction of EMI; they mainly point to insufficient language skills of staff members (Wächter/Maiworm 2008: 41). The capability argument might be backed by the observation that older university staff and staff less accustomed to EMI tend to voice the most criticism of EMI programs (Jensen/Thøgersen 2011). Connected to this observation is the credibility argument. A perceived lack of competence in English, such as strong accents or repeated pronunciation mistakes, tends to be associated with poor lecturing skills and less credibility with students (Jensen et al. 2013). Central to this paper is the third perspective on EMI, the inequality perspective. Due to its complexity, it comprises many different and sometimes contradictory perspectives. Some scholars are inclined to foresee a segregation between an English-speaking elite and a non-English-speaking majority (Harder 2009: 8) or they adduce the possibility of higher costs for nonnative English speakers to make their voices heard at the level of international scientific discourse (Ammon 2001). Thus, this perspective refers to political segregation on a global or national level. Others point to disadvantages for lower strata students (Lueg/Lueg 2015) and to the reproduction of elites through specialized programs and institutions with English language traditions (Berg et al. 2001; Vaara/Faÿ 2012), thus leading to inequality on the level of social strata and agents. The main arguments of the inequality perspective are developed further in section four below. The fear of a national domain loss leads to the fourth perspective, which sometimes focuses on politicized ideas such as a nation's right to maintain its own language or protection against a perceived threat to national identity. The ideological opposition against English (including EMI) is summarized by a study that shows that Finns believe that English endangers the "purity and integrity of Finnish society and culture " and is associated with "a range of destructive, disruptive, harmful and violent phenomena and entities. Similarly, the impact of English is argued to be pervasive, seductive, corruptive and harmful, affecting individuals and social groups and their minds and language practices« (Leppänen/Pahta 2012: 161). Such perspectives often fan the flames of xenophobic sentiments and are at times even employed by nationalistic movements, such as when Denmark's far right Dansk Folkeparti (Danish People's Party) suggests that English should be banned in academia (DF 2009). Thus, in general, the current European perspectives on EMI can be characterized as rather negative. Arguments advocating EMI typically focus on its use for business, career and economy. The current paper, despite its critical contribution, finds this debate incomplete and argues for an extension of those perspectives that support EMI.

Table 1: Three perspectives on EMI*

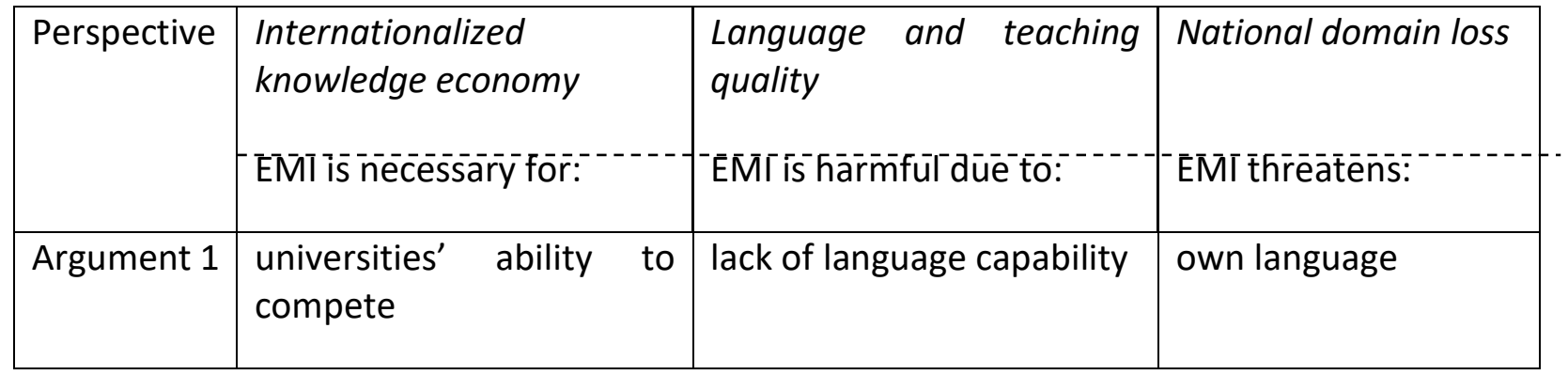




\begin{tabular}{|l|l|l|l|}
\hline Argument 2 & students' careers & loss of lecturer credibility & national identity \\
\hline
\end{tabular}

*For the fourth perspective, the inequality perspective, s. table 2.

\section{Internationalization and EMI in Germany}

This section presents a brief outline of perspectives and arguments regarding EMI in Germany and then reports the current status of HE internationalization and EMI in Germany. In general, the German debate regarding EMI resembles the European debate (s. section two) in terms of its central perspectives. Certain objections can be subordinated - to a certain extent - under the language and teaching quality perspective outlined earlier. What seems to be special in Germany, however, is the connotation of the axiomatic superiority of the German language. Press coverage, in particular, seems to rise against the perceived imposition of a language that is considered less precise and multifaceted than German. The attitude that "the non-conversant converse in English « ${ }^{2}$ ("Wer nichts zu sagen hat, sagt's auf Englisch", Endres 2007) is frequent. English - and particularly English loanwords - often encounter some opposition and even political intervention (Michael Clyne 1995; mmq/dapd 2010). Commentaries on the use of EMI or English as LHE often quite emphatically point to the loss of appealing rhetoric (e.g. Klein 2007). The claim that "people are not able to express themselves in a second or third language as well as they do in their mother tongue «* (Rehländer 2013) is echoed in different variations. The chairman of the German Rectors' Conference, in a comment that was critical of EMI, claimed that inspiring lecturers need "wit and more "*, which is best expressed in their first language (Vitzthum 2012). One of the few deliberative journalistic comments on the matter ironically stated: "To put it differently: He who thinks in a foreign language is mentally retarded. "* (Wiarda 2012). The capability argument, too, exists in Germany. Those German universities that do not offer EMI programs tend to explain their decision by pointing to the lack of academic staff with sufficient language skills (Wächter/Maiworm 2008: 42). Knapp's (2011) observations on the particularly severe communication challenges of lecturers applying EMI seems to confirm this principle. However, it seems reasonable to expect these capability issues to lose momentum, based on the results of recent studies on the Germans' English capability. The EF English proficiency index ranks Germany $10^{\text {th }}$ out of 70 countries (EF_EPI 2014). Furthermore, 86 percent of the German respondents surveyed by the Special Eurobarometer on language use supported the claim that "Everyone in the European Union should be able to speak one language in addition to their mother tongue«. This multilingual European is represented by students (Commission 2006: 4), lending reason to believe that capability problems are not a pressing issue among the student population. Moreover, Hilgendorf (2007) concluded that frequent and sometimes routinized English language use is an overall social reality in German everyday life. Further arguments can mainly be found within the

\footnotetext{
${ }^{2}$ All translations from the original German are mine and are hereafter marked with an asterisk, K.L.
} 
inequality perspective. Some newspaper articles point to the dilemma that EMI causes for incoming international students. On the one hand, EMI is a means to fast and unhindered study success for those foreign students whose English is better than their German. On the other hand, EMI proves to be a bad investment for those who wish to remain in Germany after graduation and find that their employment chances are reduced if they are not fluent in German (Hoffmeyer 2012). Furthermore, opponents warn against social splits caused by English requirements (Moser 1985, cited in Hilgendorf 2007). An author at the Goethe-Institut even fears a »divide between scientists and the rest of the society (Fiebach 2010). The perspective of national domain loss might gain ground in Germany as well. The recent formation of a political group protesting several issues that they interpreted as influenced by American politics (Patriotic Europeans against the americanization of the Christian West, aar/dpa 2015) might point to a nationalistic anti-English development in Germany. The perspective of the international knowledge economy forms the basis of governmental HE politics. The Joint Science Conference (GWK 2013) that is in charge of a common German research strategy suggests that a) the members of university staff should at least have a command of spoken English and b) large segments of study programs, particularly on the MA and PhD levels, should be offered in English or other foreign languages (GWK 2013: 5). Students seem to value EMI (Knapp 2011) and understand it as a means of distinction in the field of HE (Bloch et al. 2014: 253). Thus, the career argument is also of importance in Germany, particularly among students at private HE institutions. The use of EMI, or English as a working language, is of central importance in the impression management of these organizations (Blochet al. 2014).

With respect to the internationalization of the German HE landscape in general, internationalization or internationality seems to pose a politically encouraged (Brandenburg/Knothe 2008) means of distinction in Germany. The German Rectors' Conference spurs competition by offering a seal of »internationalization « to universities (HRK 2014). Such strategies seem to have an effect. Bloch et al. (2014) convincingly connected the employment of internationalization-related selfdescriptions of private HE institutions to stratification in the HE sector. Brandenburg \& Knothe (2008) estimated that 46 percent of their sample of HE institutions had an internationalization strategy with a measurement catalog. More than half of all HE institutions (56\%) offer programs that are marked as »international« (Maiworm 2014). However, estimating the role of EMI in these programs is problematic because institutional definitions of »international « vary widely. A search of the German academic exchange service's database reveals that German HE institutions currently offer 932 full EMI programs (B.A., M.A., PhD) (DAAD 2015a). Of these programs, 695 are B.A. and M.A. programs. If private programs that charge high tuition are excluded, 457 B.A. and M.A. programs remain. The EMI offerings are not evenly spread across disciplines. The leading disciplines or subjects $(n=695)$ are Natural and Computer Sciences (310 programs), Economics \& Business Studies (245), and Engineering (237), followed by Social Sciences (66). Very few 
EMI programs were offered in the field of Philosophy and Languages, and the field of Education/Teacher Training had only one program (DAAD 2015a) ${ }^{3}$. The distribution roughly resembles Wächter's and Maiworm's (2008: 47) classification, in which Engineering programs were offered most, and education/teacher training had zero programs. With respect to the current paper, the rationales behind EMI offers are relevant. Maiworm (2014: vi) reported that offering such EMI programs predominantly addresses foreign students with limited German language skills and, to a lesser extent, domestic students. The need to accommodate the expectations and desires of incoming international students and staff for EMI is reasonable. The website study-in.de indicates that Germany is the "third most popular destination among international students in the world " (DAAD 2015b). According to the website, more than 12 percent of students at German universities come from abroad (s. also Maiworm 2014: ii: 16.1\% first year students in 2012). Furthermore, 10.2 percent of academic staff members and 6.3 percent of professors who were employed in 2012 were internationals (Maiworm 2014: ii).

This focus on mobility can be problematized since "Internationalization at home« (for a recap of notion and debate s. Teekens 2015) and domestic students' increasing demand for EMI programs seem to be overlooked. Internationalization seems to be understood within the traditional frame of the nation state and as an accommodation to the needs of incoming internationals rather than as a trans-border qualification for international and domestic students (for a similar discussion s. Bloch et al. 2014: 252) and for mobile and non-mobile students. German students' strong interest in EMI is demonstrated by the fact that "Germans by far constitute[d] the largest group of students in early EMI programs (Hilgendorf 2005). Overall, the discussion of EMI in German HE must consider that the EMI target group is in fact both domestic and foreign.

\section{Discussion of central perspectives on internationalization, EMI, and inequality}

Claims connected to inequality are frequently substantial elements of the EMI and internationalization debate (s. section 2). These arguments are of a very different character and are not necessarily compatible with one another, and they sometimes comprise arguments from other perspectives. In the following, common arguments relating to inequality are listed and discussed (s. table 2 for overview). EMI must be considered in the context of both English as LHE and the process of internationalization, and overlaps are inevitable.

\footnotetext{
${ }^{3}$ Categories as listed by DAAD 2015a; double-listings not excluded; not all categories listed.
} 


\section{EMI/English as the language of HE leads to a social gap between scholars and the rest of society.}

This point of view, as previously discussed, is voiced repeatedly in Europe. Indeed, it is safe to say that gaps between scholars and other parts of society are well documented in many respects (Bourdieu 1984; 1988; Leshner 2015; Peters 2012) and that this divide is enhanced by the language code applied in HE (Bourdieu/Passeron 1977; Bourdieu et al. 1994). However, English as LHE cannot be held responsible for this existing alienation, as scholarly lingo has previously performed this alienating function without English language influence. In fact, a more interesting topic may be whether English as LHE might even help overcome social alienation, that might occur e.g. in the professional English-speaking business sector (Hilgendorf 2007). It might also concern groups that feel socially distanced from traditional German academic lingo. The English writing style, in contrast to German habits (although these too are both traditional and changing), has a strong reader orientation (M. Clyne 1987; Siepmann 2006), and the English intellectual style of debate is described as more »tolerant" and less »elitist" than the German style (Galtung 1981; Siepmann 2006).

\section{The EMI program of a non-native speaking teacher will always be of poorer quality than the EMI program of a teacher in her first language, which discriminates EMI students against those studying in their first language.}

This particular stance is found in the media (Klein 2007; Rehländer 2013) and has been backed by selected scholars (Vitzthum 2012). However, no study has provided systematic evidence for EMI-related quality decrease, content loss and poorer learning outcomes or grades when taught by non-native English speakers. Danish students associate strong accents and pronunciation mistakes with poor lecturing skills (Jensen et al. 2013), but this problem seems to unveil itself as a problem of attitude toward English (Jenkins 2009). Many scholars and students seem to accept the concept of an exclusive British linguistic and pronunciation standard. For example, at Aarhus University, Denmark, a booklet on British writing standards prompts the employees to "write correct English «, hereby rendering, implicitly, U.S. and other Englishes as incorrect (AU_Language 2015). In fact, English can be seen as a language without ownership (Jacobsen 2017), and numerous Englishes are constantly being developed (B. B. Kachru 1992). The concept of World Englishes rejects the "traditional dichotomy between native and non-native» as "functionally uninsightful and linguistically questionable« (B.B. Kachru 1988a, cited by B. B. Kachru 1992). Rather than being subordinate to one language standard, students should have the chance to become accustomed to a variety of accents, pronunciations and vocabulary, effectively mirroring the global variety and distribution of Englishes. Labeling pronunciation variations as »mistakes« shows the complicity of non-native speakers to bolstering the symbolic power of an English that is considered superior (Bourdieu 1991: 163-164), resulting in self-exclusion from equal discourses. Furthermore, the quality loss argument cuts both ways. In countries in which university teachers 
advocate for using EMI, quality loss is described as stemming from studies translated from English and the dismissal of English language sources (Zare-ee/Gholami 2013). As a whole, this stance does injustice to non-native English speaking scholars in the world's outer and expanding circle of English and questions the teaching quality in institutions in which EMI serves as lingua franca (e.g., in India, Tanzania) (Y. Kachru/Nelson 2006).

\section{Internationalization - and EMI as one prominent indicator of internationalization - es- tablishes inequality among HE institutions.}

The stratification of German HE institutions by internationalization was recently investigated by Bloch et al (2014). Internationalization and internationality are used for impression management by both publicly funded graduate schools and private schools. Bloch et al. found that students view EMI as an attractive sign of internationality (Bloch et al. 2014: 255). Internationality and EMI seem to have become bullet points for scoring distinction. Bloch et al. problematized the conceptualization of internationalization/internationality as a nation-state oriented "exchange" focused on outnumbering others (e.g., most partner institutes). If EMI is reduced to quantitative performance figure only, it can indeed contribute to creating a (meaningless) hierarchy and stratification rather than to creating an integrative and globally accessible organization.

\section{EMI contributes to the exclusion of non-English language content. It thus establishes a hierarchy between English and other language publications, perspectives and research traditions.}

A recent network science study on the connectivity of languages showed, indeed, that "the world's languages exhibit a hierarchical structure dominated by a central hub, English « (Ronen et al. 2014). In academia, a scholar's ability to disseminate ideas to a large number of people increases her chances of influencing scientific development. EMI syllabi are in danger of favoring publishing houses, texts, and consequently the dissemination of ideas that are connected to native speakers, particularly to those in culturally dominant regions. Traditions and concepts from speakers of less connected languages might become lost. This knowledge asymmetry has been addressed by Ammon (2012), who indicated that the focus on English excludes contributions from Asian countries, Russia, Germany, Italy and France.

Knowledge dissemination biases are observable in business-related subjects that established EMI earlier than other disciplines. Engwall (2004) documented how the Anglo-Americanization of Scandinavian business schools has led to both a change in language and a general shift in tradition toward an American focus on finance and microeconomics. Critical management scholars have investigated various aspects of internationalized management education (Doh 2010), such as the 
diffusion of Anglo-American concepts and values (Krishnan 2008; Sturdy/Gabriel 2000). One explicit example of such knowledge asymmetry is the ignorance of the early conceptualizations of cost allocation (»Prozesskostenrechung") in Germany (Schmalenbach 1899). The American equivalent, "activity based costing " was not developed until 1988 (Cooper/Kaplan 1988), yet this moment is considered as this costing type's hour of birth. In general, missing or delayed translations of European work into English and differences in textbook or research field foci pose challenges (s. e.g., American vs. French and German research and the theory of social inequality). These challenges limit choices and raise the workload for translations, literature research and syllabus planning. Finally, even more than a particular language, a specialized lingo such as "management grammar (Vaara/Faÿ 2011; Vaara/Faÿ 2012) reveals a particularly distinctive character in the field of HE. A certain management lingo might incorporate problematic values, e.g., neo liberal values, and create an uncritical discourse (Vaara/Faÿ 2012). Furthermore, a specialized lingo is even more difficult for non-native speakers to acquire than a standard language as a means of communication. Thus, at present, EMI and English as LHE contribute to global inequalities and knowledge bias.

\section{English is part of a capital of international orientation and stratifies students in EMI programs against those studying in their $L 1$.}

At the outset, it is important to note that Bourdieusian theory is crucial for understanding the role of EMI in the formation of elites and inequalities. Embodied cultural capital covers competences and knowledge that are imparted during socialization. Institutionalized cultural capital is formed with credentials from authorized institutions (Bourdieu 1997: 47-48). Symbolic capital grants credibility and distinction and consists of other types of capital that are recognized as legitimate (Bourdieu 2005: 195). "[L]inguistic capital « is described as appendant to embodied cultural capital and co-determines academic success (Bourdieu/Passeron 1977: 73; Bourdieu et al. 1994b: 37). It can be conjectured that (1) family background has an indirect effect on the choice of EMI and (2) EMI functions as distinguishing symbolic capital in selected fields (Bourdieu 1991: 55). Following the career argument (s. sections 2 and 3 above), EMI facilitates access to desirable positions and professions. Thus, it becomes a vehicle for the creation of social capital, i.e., social belonging, and economic capital, i.e., income. EMI as symbolic capital must be viewed in the context of attitudes toward English and internationalization. In Germany, EMI can positively affect students' choice of selected HE institutions, and international CVs of lecturers are viewed as prestigious (Bloch et al. 2014). Hilgendorf has narrated examples of "accommodating, even deferential« attitudes toward English in German everyday life encounters (Hilgendorf 2007: 141). Most importantly, Prieur and Savage (2011: 575), in their exploration of capital signifiers in modern societies, noted that one of the differences between the culturally privileged and non-privileged

in Denmark is a difference in »international vs. local or national orientation « (for a similar conceptualization of cosmopolitanism s. Igarashi/Saito 2014). In the Netherlands, parents perceive international education as a cultural and social capital investment (Weenink 2008). 
In their study of first-semester students $(n=706)$ at Aarhus University, Denmark, Lueg and Lueg (2015) showed that social background substantially affects students' choice of EMI. Students were offered two identical programs (B.A., economics and business administration) that differed only in the medium of their instruction (English or Danish). The study showed that EMI attracted higher strata students; these students choose EMI nearly 50 percent more often than lower strata students. English proficiency in itself is not decisive. All students proved that they had outstanding English proficiency to be admitted into the study program. Yet, higher strata students' self-ascription of English proficiency was higher. The barriers and fears associated with EMI gained more weight with decreasing strata. Students, particularly from the lower strata, feared receiving lower grades or missing content despite their documented English proficiency. They opted against EMI, even if they explicitly expressed seeing benefits in EMI education and acknowledged its function as a type of capital. Thus, rather than reflecting incapacity or lack of insight, the decision not to choose EMI programs reflects distance from doxical field correspondence (Bourdieu 1998: 81) and the mediating effect of habitus as a "sense of one's place" (Bourdieu 1984: 471). This decision ties in with Knapp's (2011: 61) observations in Germany that students opting for German classes show »a pronounced awareness of the benefits of EMI«. Most of their arguments "refer to the improvement of their language abilities, followed by usefulness for their future jobs."

Lueg \& Lueg (2015) further noted that females of the lower and middle strata opted for EMI much more frequently than their male peers. In stratum 2 (middle), 9.9 percent of the females chose EMI, as opposed to 2.5 percent of the males. In stratum 1 (lower middle), 31 percent of the females chose EMI, as opposed to only 8.0 percent of the males. In sum, males from higher strata and females from lower strata tended to choose EMI. Hence, the choice of EMI was determined by both social strata and gender. Departing from the notion of EMI as symbolic capital, EMI will likely function as structuring structure (Bourdieu 1990: 53) and further reproduce distinction and unequal opportunities in professional pathways. An unmindful implementation of EMI may thus contribute to social inequality.

Table 2: The inequality perspective on EMI: overview of arguments and discussion

\begin{tabular}{|l|l|l|}
\hline Argument & Objection & Outlook \& Implication \\
\hline $\begin{array}{l}\text { EMI leads to a social gap be- } \\
\text { tween scholars and others } \\
\text { alienation, not EMI }\end{array}$ & $\begin{array}{l}\text { Gaps are caused by social } \\
\text { the avenue to overcoming aliena- } \\
\text { tion }\end{array}$ \\
\hline $\begin{array}{l}\text { Low quality of non-native EMI } \\
\text { discriminates in favor of EMI } \\
\text { students against those study- } \\
\text { ing in domestic language }\end{array}$ & $\begin{array}{l}\text { No evidence for learning } \\
\text { impairment }\end{array}$ & HE must acknowledge \\
- the concept of "world Englishes
\end{tabular}




\begin{tabular}{|c|c|c|}
\hline & $\begin{array}{l}\text { Based on misconception of } \\
\text { one »correct« English }\end{array}$ & $\begin{array}{l}\text { - legitimacy of various pronuncia- } \\
\text { tions and expressions } \\
\text { - comprehension of various Eng- } \\
\text { lishes as a capability }\end{array}$ \\
\hline $\begin{array}{l}\text { EMI and internationalization } \\
\text { as scores establish a meaning- } \\
\text { less institutional hierarchy }\end{array}$ & None & $\begin{array}{l}\text { Politics and policy of current inter- } \\
\text { nationalization and EMI must be re- } \\
\text { explored to uncover and avoid sheer } \\
\text { impression management }\end{array}$ \\
\hline $\begin{array}{l}\text { EMI contributes to the exclu- } \\
\text { sion of non-English language } \\
\text { content }\end{array}$ & None & $\begin{array}{l}\text { Increase in EMI programs might lead } \\
\text { to the embedding of local contents } \\
\text { in globalized education (e.g., due to } \\
\text { translations of European contents) }\end{array}$ \\
\hline $\begin{array}{l}\text { EMI as capital attracts (dis- } \\
\text { courages) higher (lower) } \\
\text { strata students and repro- } \\
\text { duces inequalities }\end{array}$ & None & $\begin{array}{l}\text { Peer rather than ex cathedra learn- } \\
\text { ing } \\
\text { Continuous rather than final evalua- } \\
\text { tion } \\
\text { Acknowledgements of world Eng- } \\
\text { lishes } \\
\text { Content first policy } \\
\text { Abandon language/aesthetics as as- } \\
\text { sessment criterion } \\
\text { Teacher education }\end{array}$ \\
\hline
\end{tabular}

\section{Implementing EMI: avenues to borderless higher education}

This paper argues in favor of implementing EMI further in European countries, particularly in Germany. However, an unmindful implementation of EMI as a performance indicator in a politically encouraged internationalization process should be avoided. A carefully managed didactic integration of EMI is crucial for its success as a language of choice and to achieve equal opportunities for access. Moreover, this paper posits that EMI is one of the more adequate and effective tools for reaching the goal of further internationalizing the universities to transform them into diverse and accessible trans-border organizations. Within this framework, this paper acknowledges the career-related argument that students - even those opting against taking EMI classes 
- advocate for EMI as an avenue to careers. However, arguments related to business and economy should not be the only intercessors for EMI and internationalization. Another focus might be the conceptualization of universities as trans-border organizations that contribute to global equality of opportunities.

Research on world Englishes provides beneficial perspectives in this regard. Specifically, EMI might provide non-native speaking communities with the opportunity to strengthen their positions in global academia, to participate in global thought exchange and to overcome languagerelated barriers. These outcomes are only possible if EMI is detached from the ownership of selected mother tongue speakers and language idealism. In Germany, a focus on rhetoric in lectures, which is supposedly connected to a first language, seems to operate in EMI's disfavor. Furthermore, imperfections in English language capability seem to be perceived as a problem. Lecturers and university management might draw upon the insights of world Englishes to overcome the ideal of one correct English. Students should be encouraged to cultivate skills in understanding different Englishes to mirror later professional encounters on the world stage and in the world economy. The use of the focus on language aestheticism for content learning at the university level should be questioned. Lecturers should be offered classes on EMI and/or international classroom teaching, in addition to Academic English(es). Such offerings are extensive in Denmark (partly as mandatory pedagogical training for tenure admission) and widespread in the Netherlands (Klaassen/De Graaff 2001). EMI programs provide the opportunity to achieve internationalization at home. When applied in the sense of world Englishes, EMI might represent a qualitative counterweight against merely quantitative listings of collaborations abroad or student exchanges. Internationalization at home makes internationality accessible for non-mobile students. Combined with e-learning, or at least with blended learning concepts, EMI currently provides the best opportunities to offer trans-border education and attract a super-diverse student body (Vertovec 2007) beyond segregating concepts of legal, national or linguistic belonging.

Such offers both make study programs in Germany accessible to foreign students and acknowledge the demand of domestic students. The latter is of high importance for the political framing of internationalization and EMI introduction. A one-sided perspective on EMI target groups might foster the misconceptions that a) a minority of incoming foreign students imposes EMI on domestic students and staff who prefer instruction in German and b) as a consequence, the minority should adapt to the majority, that is, should learn German. These points tie in with the necessity of rediscussing the notion of internationalization and internationality in general. While initially providing opportunities for accessible education, these notions have been harnessed by HE management to compete in the HE market. This paper cautions against diminishing EMI programs to quantitative performance figures that contribute to ranking HE institutions.

Other factors that have implications for the use of EMI include global knowledge asymmetries and the loss of traditions and cognitive models in languages other than English. Whereas opponents argue to decrease EMI programs, this paper argues that an increase in EMI programs and 
English as LHE will be more efficient in achieving a balance in the mediation of local and global contents. A higher intake of students in EMI programs might provide cost advantages that allow the translation and publication of local and national content (e.g., translations of European content rather than imported Anglo-American content based on English language textbook availability).

With respect to students' attitudes toward and choice of EMI, universities should acknowledge that EMI can perpetuate existing social inequalities (Lueg/Lueg 2015). Working on the students' English language capabilities does not seem to be a solution because lower strata students with documented high-level English language capabilities seem to fear lower grades or missing content. Thus, course leaders and university management should focus on countering these fears because - given comprehensibility - a lack of virtuosity in rhetoric and language style should not lead to lower marks. Assignments should reflect the students' content-related work rather than their rhetorical and linguistic abilities to avoid strata bias and to avoid awarding linguistic heritage (Baudelot 1994; Bourdieu/Passeron 1977). Such practice should be explicitly discussed in course descriptions. A change in didactics can further contribute to an altered perception of the barriers. Such a change might involve replacing one final exam with a continuous assessment to account for student development and performance deviations. Pressure can be lowered by reorganizing large ex cathedra lectures into peer tutoring formats (Lueg/Lueg 2014). Small-sized peer tutoring groups lessen individuals' fear of speaking up in a second language and, thus, address problems such as lack of discussion or participation in EMI courses (Knapp 2011: 60). A certain amount of parallel language use in domestic language seminars might also contribute to lowering barriers. The integration of reader-friendly English language texts and journal articles in early classes would help students become accustomed to English writing styles and academic vocabulary. Ideally, EMI should be offered as a choice for students. In large programs, this choice can be provided through parallel EMI and domestic language tracks. In small programs, students might opt for EMI electives. Confronting students with mandatory EMI should be avoided at this time because the evidence concerning fear-related choices indicates that students might drop out of the program.

The implications discussed above provide an avenue for future research. EMI and HE internationalization are fruitful areas for a wide array of disciplines, ranging from the studies of elite formation, critical management and higher education to language and translation studies. Importantly, more research on domestic students' motives for supporting EMI is required to explore those rationales beyond economic motives. This research could reframe the political debates on $\mathrm{EMI}$ and internationalization and obviate political framing of incoming students as enforcers of EMI. Similarly, there is a lack of knowledge on the extent of English language literature in nonEMI course syllabi. Surveying course readings might reveal the degree to which students in nonEMI classes are accustomed or not accustomed to the use of English. Finally, this research might shed light on why students shy away when confronted with EMI classes with full English language syllabi. A related useful progression would be the investigation of national concept and tradition 
loss. Surveying concrete examples in class planning can raise awareness about the issue of inequalities in global knowledge dissemination.

Concerning HE didactics, classroom observations of different instruction formats might reveal best practice models for integrative and effective EMI classes.

More generally, the issue of internationalization and fundamental identity construction of $\mathrm{HE}$ institutions requires some attention. It has been shown that $\mathrm{HE}$ internationalization continues to be strongly viewed through a (competitive) nation state lens. In this view, HE institutions are considered manifest service institutions to one nation state. Thus, internationalization can be harnessed as a competitive performance indicator, reduced to impression management or used to segregate political arguments. The extent to which HE organizations are free or economically constrained to construct their own identity on the global market should be explored. Such an identity might be that of a local representation of accessible trans-border education, e.g., with elearning using EMI. Finally, concerning longitudinal insights into stratification and the formation of elites, research on the choice between EMI and Danish medium instruction (Lueg/Lueg 2015) might serve as a valuable basis for studies in contexts with more social stratification and/or lesser English capabilities, such as in Germany. English language might be a slightly stronger social separator due to lower general English proficiency (EF_EPI 2014). Compared with Denmark and other northern European countries, the stronger presence of social selection bias and stratifying effect of German HE (Hartmann 2010; Isserstedt et al. 2010) combined with a smaller percentage of HE-qualified college graduates must be considered (Orr et al. 2011; Uddannelses- og Forskningsministeriet 2014; UNDP 2011). Moreover, connections between study strategies and within-field differentiation of the German HE system and the formation of professional elites have been uncovered (Hartmann 2000; 2002). Hartmann has shown that both HE and its noninstitutionalized equivalent "Allgemeinbildung" and the right habitus (Hartmann 1996; 2000; 2006) are main dividers between the social milieus and contribute to reproducing unequal opportunities. However, to date, within-field stratification of the German HE system, such as private schools or graduate programs funded or self-promoted as "elite», does not seem to impact the formation of corporate elites (Hartmann 2015). Simultaneously, international studies and Bloch et al.'s recent observations on within-field stratification in German HE have described the increasing importance of cosmopolitanism, internationalism and EMI (Bloch et al. 2014; Igarashi/Saito 2014; Weenink 2008). In the long run, it will be highly relevant to observe whether the effect of internationalization on within-field stratification will be mirrored by student stratification and elite formation of graduates in Germany.

\section{References}

aar/dpa., (2015). Pegada in Erfurt: Hunderte demonstrieren gegen "Amerikanisierung des Abendlandes". Spiegel online. 
Aba, D., (2013). Internationalization of higher education and student mobility in Europe and the case of Turkey. Çukurova University. Faculty of Education Journal. 42(2), 99-110.

Aittola, H. et al., (2009). The Bologna Process and Internationalization - Consequences for Italian Academic Life. Higher Education in Europe. 34(3-4), 303-312.

Ammon, U., (2001). Editor's Preface. In U. Ammon (Ed.), The dominance of English as a language of science. Effects on other languages and language communities. Berlin: De Gruyter.

Ammon, U., (2012). Linguistic inequality and its effects on participation in scientific discourse and on global knowledge accumulation - With a closer look at the problems of the second-rank language communities. Applied Linguistics Review. 3(2), 333-355.

Ammon, U., McConnell, G., (2002). English as an academic language in Europe: $A$ survey of its use in teaching. 48. Bern: Peter Lang.

AU_Language., (2015). Language and Translation. Retrieved 10.02.2015, from http://medarbejdere.au.dk/en/administration/communication/languageportal/

Berchem, T., (1991). The Internationalisation of Higher Education: The German Perspective. Higher Education. 21(3), 297-304.

Berg, E.C., Hult, F.M., \& King, K.A., (2001). Shaping the climate for language shift? English in Sweden's elite domains. World Englishes. 20(3), 305-319.

Bloch, R. et al., (2014). Stratifikationen im Bereich der Hochschulbildung in Deutschland. Zeitschrift für Erziehungswissenschaft. 17(3), 243-261.

BMBF., (2014). Internationalisierung der Hochschulen 2014. Retrieved from http://www.bmbf.de/de/908.php

Bourdieu, P. (1984). Distinction: A Social Critique of the Judgement of Taste. Cambridge: Harvard University Press.

Bourdieu, P., (1988). Homo Academicus. Cambridge: Polity.

Bourdieu, P., (1990). The Logic of Practice. Stanford: Stanford University Press.

Bourdieu, P., (1991). Language and Symbolic Power. Cambridge, MA: Harvard University Press.

Bourdieu, P., (1997). The Forms of Capital. In Halsey, A.H., Lauder, H., Brown, P., Wells, A.S. (Eds.), Education, Culture, Economy, Society. Oxford: Oxford University Press. 46-58. 
Bourdieu, P., (1998). Practical Reason: On the Theory of Action. Stanford: Stanford University Press.

Bourdieu, P., (2005). The Social Structures of the Economy. Cambridge: Polity.

Bourdieu, P., Passeron, J.C., (1977). Reproduction in Education, Society and Culture. London: Sage.

Bourdieu, P., Passeron, J.C., Saint Martin, M.d., (1994). Academic Discourse. Cambridge: Polity.

Bourdieu, P., Passeron, J.C., Saint Martin, M.d., (Eds.), (1994b). Students and the Language of Teaching. Academic Discourse. Cambridge: Polity. 35-79.

Brandenburg, U., Knothe, S., (2008). Institutionalisierung von Internationalisierungsstrategien an deutschen Hochschulen. CHE Centrum für Hochschulentwicklung, Arbeitspapiere. (116), 1-43.

Byun, K. et al., (2011). English-medium teaching in Korean higher education: policy debates and reality. Higher Education. 62(4), 431-449.

Clyne, M., (1987). Cultural Differences in the Organization of Academic Texts. English and German. Journal of Pragmatics. 11, 211-247.

Clyne, M., (1995). The German language in a chaning Europe. Cambridge: Cambridge University Press.

Coleman, J.A., (2004). The language of higher education. Paper presented at the Language and the future of Europe: ideologies, policies and practices.

Commission, E., (2006). Europeans and their languages. Special Eurobarometer. Retrieved from http://ec.europa.eu/public opinion/archives/ebs/ebs 243 en.pdf.

Cooper, R., Kaplan, R.S., (1988). Measure costs right: make the right decision. Harvard Business Review. 66, 96-103.

Costa, F., Coleman, J.A., (2012). A survey of English-medium instruction in Italian higher education. International Journal of Bilingual Education and Bilingualism. 16(1), 1-17.

DAAD., (2015a). International Programmes in Germany 2015. Retrieved 26.01.2015, from DAAD - German Academic Exchange Service: https://www.daad.de/deutschland/studienangebote/international-programs/en/

DAAD., (2015b). Studying in Germany - the right choice for you! Retrieved 26.01.2015, from https://www.study-in.de/en/discover-germany/ten-reasons-for-germany 27121.php 
de Haan, H., (2014). Internationalization: Interpretations Among Dutch Practitioners. Journal of Studies in International Education. 18(3), 241-260.

DF., (2009). Arbejdsprogram: Forskningspolitik. Retrieved from http://www.danskfolkeparti.dk/Forskningspolitik.asp

Doh, J.P., (2010). From the editors: Why aren't business schools more global and what can management educators do about It? Academy of Management Learning \& Education. 9(2), 165168.

EF_EPI., (2014). EF English Proficiency Index. Retrieved 26.02.2015, from http://www.ef.co.uk/epi/

Endres, H., (2007). Jetzt mal Klartext. manager-magazin.de. Retrieved from http://www.manager-magazin.de/magazin/artikel/a-495097-2.html

Engwall, L., (2004). The Americanization of Nordic management education. Journal of Management Inquiry. 13(2), 109-117.

Ennew, C., Greenaway, D., (2012). The globalization of higher education. New York: Palgrave Macmillan.

Fiebach, C., (2010). Deutsch als Wissenschaftssprache - deutsche Sprache, quo vadis? Goethe Institut e.V. Online Redaktion.

Galtung, J., (1981). Structure, Culture and Intellectual Style. Social Science Formation. 20, 817856.

Haastrup, K., (2008). English-medium higher education in Denmark. Nordic Journal of English Studies. 7(3), 205-206.

Harder, P. (Ed.), (2009). English in Denmark: Language Policy, Internationalization and University Teaching. 9. Copenhagen: Museum Tusulanum Press. University of Copenhagen.

Hartmann, M., (1996). Topmanager - Die Rekrutierung einer Elite. Frankfurt a.M.: Campus.

Hartmann, M., (2000). Class-specific Habitus and Social Reproduction of the Business Elite in Germany and France. The Sociological Review. 48(2), 241-261.

Hartmann, M., (2002). Der Mythos von den Leistungseliten. Spitzenkarrieren und soziale Herkunft in Wirtschaft, Politik, Justiz und Wissenschaft. Frankfurt/New York: Campus.

Hartmann, M., (2006). The sociology of elites. London: Routledge. 
Hartmann, M., (2010). Achievement or Origin: Social Background and Ascent to Top Management. Talent Development \& Excellence. 2(1), 105-117.

Hartmann, M., (2015). Forthcoming study on the managerial boards of the 100 largest German companies.

Hilgendorf, S.K., (2005). "Brain Gain statt[instead of]Brain Drain": the role of English in German education. World Englishes. 24(1), 53-67.

Hilgendorf, S.K., (2007). English in Germany: contact, spread and attitudes. World Englishes. 26(2), 131-148.

Hoffmeyer, M., (2012). Studium auf Englisch. International aufgestellt. Sueddeutsche.de. 2.

HRK. (2014). Audit "Internationalisierung der Hochschulen". Retrieved from http://www.hrk.de/audit/

Igarashi, H., Saito, H., (2014). Cosmopolitanism as Cultural Capital: Exploring the Intersection of Globalization, Education and Stratification. Cultural Sociology. 8(3), 222-239.

Isserstedt, W. et al., (2010). Die wirtschaftliche und soziale Lage der Studierenden in der Bundesrepublik Deutschland 2009. 19. Sozialerhebung des deutschen Studentenwerks durchgeführt durch HIS Hochschul-Informations-System. Bonn/Berlin: BMBF.

Jacobsen, U., (2017). English in the European Union after Brexit: Inclusion effects of a language without an owner. Culture, Practice and European Policy. 2(1), 9-11.

Jenkins, J., (2009). English as a lingua franca: interpretations and attitudes. World Englishes. 28(2), 200-207.

Jensen, C. et al., (2013). Students' attitudes to lecturers' English in English medium higher education in Denmark. Nordic Journal of English Studies. 12(1), 87-112.

Jensen, C., Thøgersen, J., (2011). Danish University lecturers' attitudes towards English as the medium of instruction. Iberica. 22, 13-33.

Jeong, Y.K., (2004). A chapter of English teaching in Korea. English Today. 20(02), 40-46.

Kachru, B.B., (1992). World Englishes: approaches, issues and resources. Language Teaching. 25, 1-14.

Kachru, Y., Nelson, C.L., (2006). World Englishes in Asian Contexts. Hong Kong: Hong Kong University Press. 
Kang, H.S., (2012). English-only instruction at Korean universities: Help or hindrance to higher learning? English Today. 28(01), 29-34.

Kim, T., (2009). Transnational academic mobility, internationalization and interculturality in higher education. Intercultural Education. 20(5), 395-405.

Klaassen, R.G., De Graaff, E., (2001). Facing innovation: preparing lecturers for English-medium instruction in a non-native context. European Journal of Engineering Education. 26(3), 281-289.

Klein, S., (2007). Wissenschaftssprache. Dümmer auf Englisch. Frankfurter Allgemeine Zeitung.

Knapp, A., (2011). When comprehension is crucial. Using English as a medium of instruction at a German university. In De Houwer, A., Wilton, A. (Eds.), English in Europe today: Sociocultural and Educational Perspectives. Amsterdam: John Benjamins Publishing Company. 51-70.

Kreber, C., (2009). Different perspectives on internationalization in higher education. New Directions for Teaching and Learning. 2009(118), 1-14.

Krishnan, V.R., (2008). Impact of MBA education on students' values: Two longitudinal studies. Journal of Business Ethics. 83, 233-246.

Kristensen, J.E., Nørreklit, H., Raffnsøe-Møller, M. (Eds.), (2011). Introduction: University Performance Measurement at Danish Universities. University Performance Measurement. Copenhagen: DJ $\varnothing$ F Publishing. 7-17.

Leppänen, S., Pahta, P., (2012). Finnish culture and language endangered - language ideological debates on English in the Finnish Press from 1995 to 2007. In Blommaert, J. et al. (Eds.), Dangerous multilingualism. Northern perspectives on order, purity and normality. New York: Palgrave Macmillan. 142-176.

Leshner, A.I., ( 2015). Bridging the opinion gap. Science. 347(6221), 459.

Lueg, K., (2014). Performance measurement at universities: studying function and effect of student evaluations of teaching. Journal of Organizational Knowledge Communication. 1(1), 4861.

Lueg, K., (2015). English as a medium of instruction at Danish universities: status, perspectives, and implications for higher education executives. Communication and Language at Work.

Lueg, K., Lueg, R., (2014). From Teacher-Centered Instruction to Peer Tutoring in the Heterogeneous International Classroom: A Danish Case of Instructional Change. Journal of Social Science Education. 13(2), 39-62. 
Lueg, K., Lueg, R., (2015). Why do students choose English as a medium of instruction? A Bourdieusian perspective on the study strategies of non-native English speakers. Academy of Management Learning and Education. 14(1).

Maassen, P., Uppstrøm, T.M., (2004). Internationalization of higher education institutions in Northern Europe in the light of Bologna: rethinking Nordic cooperation in higher education. Oslo: NIFU STEP.

Maiworm, F., (2014). Internationalität an deutschen Hochschulen. Fünfte Erhebung von Profildaten 2014. Gesellschaft für empirische Studien (GES).

Maringe, F., Foskett, N., (2013). Globalization and internationalization in higher education: theoretical, strategic and management perspectives. London: Bloomsbury Academic.

mmq/dapd., (2010). Kampf gegen Anglizismen: Ramsauer feiert sich als Sprachpfleger. Spiegel online.

OECD., (1999). Quality and internationalisation in higher education. Paris: OECD.

Orr, D., Gwos, C., Netz, N., (2011). Social and Economic Conditions of Student Life in Europe. Synopsis of indicators. Final report. Eurostudent IV 2008-2011. Bielefeld: W. Bertelsmann Verlag.

Peters, H.P., (2012). Das Verhältnis der Wissenschaft zur öffentlichen Kommunikation. In Dernbach, B., Kleinert, C., Münder, H. (Eds.), Handbuch Wissenschaftskommunikation. Wiesbaden: Springer VS. 331-340.

Prieur, A., Savage, M., (2011). Updating cultural capital theory: A discussion based on studies in Denmark and in Britain. Poetics. 39(6), 566-580.

Rehländer, J., (2013). "Not amused". Wider den Englisch-Wahn an Universitäten. focus.de.

Ronen, S. et al., (2014). Links that speak: The global language network and its association with global fame. Proceedings of the National Academy of Sciences. 111(52), E5616-E5622.

Schmalenbach, E., (1899). Buchführung und Kalkulation im Fabrikgeschäft. Deutsche MetallIndustrie-Zeitung. 15, 98-172.

Science, D.M.o.H.E.a., (2015). studyindenmark.dk. Retrieved from http://studyindenmark.dk/study-options/study-options

Siepmann, D., (2006). Academic Writing and Culture: An Overview of Differences between English, French and Germany. Meta: Translators' Journal. 51(1), 131-150. 
Strategie der Wissenschaftsminister/innen von Bund und Ländern für die Internationalisierung der Hochschulen in Deutschland (Beschluss der 18. Sitzung der Gemeinsamen Wissenschaftskonferenz am 12. April 2013 in Berlin) (2013).

Sturdy, A., Gabriel, Y., (2000). Missionaries, Mercenaries Or Car Salesmen? MBA Teaching In Malaysia. Journal of Management Studies. 37(7), 979-1002.

Teekens, H., (2015). Internationalisation at home - crossing other borders. University World News. (353).

Uddannelses- og Forskningsministeriet, x., (2014). Status for opfyldelse af 60 og 25 pct. målsætningerne. Retrieved from http://ufm.dk/uddannelse-og-institutioner/statistik-oganalyser/frafald-studietid-fuldforelse/bilag-1-status-for-opfyldelsen-af-60-og-25-pct-

malsaetningerne.pdf

UNDP., (2011). Human Development Report 2011. Sustainability and Equity: A Better Future for All. New York: United Nations Development Programme.

Vaara, E., Faÿ, E., (2011). How can a Bourdieusian perspective aid analysis of MBA education? Academy of Management Learning \& Education. 10(1), 27-39.

Vaara, E., Faÿ, E., (2012). Reproduction and Change on the Global Scale: A Bourdieusian Perspective on Management Education. Journal of Management Studies. 49(6), 1023-1105.

Vertovec, S., (2007). Super-diversity and its implications. Ethnic and Racial Studies. 30(6), 10241054.

Vitzthum, T.S., (2012). Es ist falsch, wenn nur Englisch gesprochen wird. Welt online. Retrieved from http://www.welt.de/politik/deutschland/article106252104/Es-ist-falsch-wenn-nurEnglisch-gesprochen-wird.html

Wächter, B., Maiworm, F., (2008). English-Taught Programmes in European Higher Education. The Picture in 2007. Bonn: Lemmens.

Weenink, D., (2008). Cosmopolitanism as a Form of Capital: Parents Preparing their Children for a Globalizing World. Sociology. 42(6), 1089-1106.

Wiarda, J.M., (2012). Wissenschaftssprache. English please! zeit.de. 2. Retrieved from http://www.zeit.de/2012/32/C-Wissenschaftssprache

Zare-ee, A., Gholami, K., (2013). Academic justifications for preferring English as a medium of instruction by Iranian university teachers. Proceeding of the Global Summit on Education. 121(429-431). 